https://doi.org/10.18485/iipe_postsovjet.2021.ch12

Јованка Кувекаловић-Стаматовић¹

\title{
Неутралност Републике Украјине: одржива политика у новим околностима
}

\begin{abstract}
Ancmpaкm: Окончање рата на Криму и замрзавање конфликта у Донбасу условили су рађање нове спољнополитичке епохе за Републику Украјину. У садржају њених послератних, институционалних докумената преовладава наратив о Русији као „агресору“ којем се делигитимизује његово историјско право, а као нови стратешки циљ одређује партнерство са НАТО савезом. Безбедносна и одбрамбена политика Украјине након 2014. године постаје наклоњена Северноатлантском савезу, због чега су неретко покретане дискусије о њеном евентуалном чланству. Реалне шансе за овакав сценарио се умањују сагледавањем руске перспективе, али и одлуке НАТО алијансе да у своје чланство не прихвата државе које на својој територији имају замрзнути конфликт. Добар пример на који се Украјина може угледати јесте Грузија, чије искуство одражава непоколебљив став Северноатлантске заједнице према одбијању земаља са спорним територијама. Из наведеног произилази да тињајући сукоби ниског интензитета подстичу државе на усвајање различитих безбедносних стратегија. Ако њихову успешност процењујемо на основу амплитуде „одмрзавања“ конфликата, онда се може закључити да је њена вредност најнижа код војно неутралних земаља. Узимајући у обзир све наведене чиниоце, основна претпоставка од које се полази у раду је да стална неутралност Републике Украјине води одрживој политици балансирања у измењеним околностима. Служећи се
\end{abstract}

\footnotetext{
${ }^{1}$ Ауторка је истраживач-приправник на Институту за међународну политику и привреду, Београд, е-пошта: jovankaks@diplomacy.bg.ac.rs.

Рад је настао у оквиру научноистраживачког пројекта „Србија и изазови у међународним односима 2021. године“, који финансира Министарство просвете, науке и технолошког развоја Републике Србије, а реализује Институт за међународну политику и привреду током 2021. године.
} 
квалитативном анализом безбедносне политике Републике Украјине, рад успева да одгонетне њен званичан став према Русији, као и реалне перспективе за чланство у НАТО. Сагледавањем различитих перспектива развија се аргументација о поновном усвајању војне неутралности, коју је Украјина заступала до 2014. године.

Кључне речи: неутралност, Република Украјина, Руска Федерација, НАТО.

\section{Уводна разматрања}

Идеја о неутралности као феномену Хладног рата погрешна је из више разлога. Као први разлог може се навести чињеница да је неутралност много старија од блоковске епохе, што потврђује и пример Швајцарске, чија неутралност датира из 15. и 16. века. Други разлог се огледа у томе да неутралност није представљала конститутивни елемент Хладног рата већ, насупрот томе, његову аномалију. ${ }^{2}$ Еволуцији неутралности од изузетка до правила допринео је распад Совјетског Савеза, када одређени број држава попут Туркменистана, Узбекистана, Молдавије и Украјине, одлучује да усвоји политику неутралности. Међутим, за потребе овог рада анализирамо неутралност Украјине у контексту билатералних односа са Русијом и евентуалног чланства у НАТО савезу, након избијања сукоба на Криму 2014. године. Ауторка полази од претпоставке да неутралност Украјине у измењеним околностима представља одрживу политику савременог балансирања између Москве, Брисела и Вашингона. Основна хипотеза рада почива на аргументацији да стална неутралност представља фактор одвраћања будућих војних интервенција у области Доњецка и Луганска. Неутралност Украјине представља актуелну тему бројних студија које такође говоре у прилог њеној одрживости, али са другачијих дисциплинарних аспеката. Према томе, у раду ће бити начињен кратак осврт на запажања других аутора, који предлажу различите моделе украјинске неутралности. Прво поглавље садржи квалитативну анализу институционалних докумената Украјине од 2014. године до данас. Кратким прегледом њиховог садржаја констатује се да неутралан статус Украјине

\footnotetext{
${ }^{2}$ Heinz Gärtner, "The Model of Neutrality The Example of East-Central European States", in: Permanent Neutrality: A model for Peace, Security and Justice, Herbert R. Reginbogin and Pascal Lottaz (eds.), Lexington Books, 2020, p. 90.
} 
има важну улогу у остваривању билатералних односа са Русијом. У другом поглављу се на основу компаративних увида са Грузијом испитују могућности евентуалног чланства Украјине у НАТО савез. Напослетку, трећи део текста сумира почетну аргументацију и разматра потенцијал предложених модела украјинске неутралности.

\section{Односи Русије и Украјине у светлу поновне војне неутралности}

Пут до званичног проглашења неутралног статуса Украјине био је динамичан будући да се по први пут помиње у Декларацији о независности из 1990. године, а потом de facto негира подношењем Акционог плана за чланство (Membership Action Plan - MAP) у НАТО. ${ }^{3}$ Интервенција Москве у Грузији била је упозорење да се сличан сценарио може догодити у Украјини, уколико Алијанса прихвати њен захтев за чланство. То је био један од повода да на самиту у Букурешту, 2008. године, НАТО савез донесе одлуку којом не одобрава придруживање двеју земаља - Грузије и Украјине. ${ }^{4}$ Политичке поделе и неуспеси на спољном плану довели су до смене власти у Кијеву, на чије чело долази Виктор Јанукович (Вїктор Фе́дорович Януко́вич). Његов повратак 2010. године означио је нову политичку оријентацију Украјине. ${ }^{5}$ Одбијањем чланства у бесцаринској унији са Русијом, Белорусијом и Казахстаном, ${ }^{6}$ нова украјинска влада закључила је споразум о слободној трговини са Европском унијом и

\footnotetext{
${ }^{3}$ Igor S. Novaković, „Politika neutralnosti u Evropi od kraja Drugog svetskog rata do danas kao „cena“ za status stalne neutralnosti: značaj za Srbiju“, u: Srđan T. Korać (ur.), Uticaj vojne neutralnosti Srbije na bezbednost i stabilnost u Evropi, 2016, str. 45-46.

${ }^{4}$ Veljko Blagojević, „Potencijal politike neutralnosti Republike Srbije u savremenim međunarodnim odnosima", u: Srđan T. Korać (ur.), Uticaj vojne neutralnosti Republike Srbije na bezbednost i stabilnost u Evropi, 2016, str. 247.

${ }^{5}$ Како пише Драган Петровић у својој књизи о председничким изборима у Украјини 2010. године, долазак Јануковича представљао је покушај одвраћања САД и НАТО да запоседну простор Украјине. Драган Петровић, Председнички избори у Украјини 2010, Институт за међународну политику и привреду, Београд, 2010, стр. 127.

${ }^{6}$ Veljko Blagojević, „Potencijal politike neutralnosti Republike Srbije u savremenim međunarodnim odnosima", op. cit., str. 248.
} 
отворила врата за улазак у Источно партнерство. ${ }^{7}$ Премда је овим потезом Јанукович оправдао своју предизборну кампању залагања, како за евроинтеграције тако и нормализацију односа са Русијом, убрзо је постало јасно да се Украјина враћа у „руску орбиту“. Недуго након промене власти Украјина је закључила споразуме који су изашли у сусрет интересима Русије. За Русију је важан био споразум којим је Украјина прихватила да продужи стационирање руске Црноморске флоте на Криму до 2042. године. У замену за то, Украјина је добила 30\% нижу цену гаса, што јој је омогућило да уштеди око четири милијарде долара на годишњем нивоу, усвоји буџет са мањим дефицитом и настави сарадњу са ММФ-ом. ${ }^{8}$ Један од уступака представљало је и усвајање Закона о неутралности, којим је напуштена политика чланства у НАТО савезу и званично проглашен ванблоковски статус земље. Међутим, нигде се није помињала тежња за сталном неутралношћу, већ се истицала економска интеграција са Европском унијом и сарадња са војним савезима. Тиме је статус „ван блокова" представљао само гаранцију моћном источном суседу да се Украјина одрекла амбиција за чланство у НАТО. ${ }^{9}$ Политика неутралности је омогућила Украјини да своје политичке маневре између Русије и Европске уније изводи несметано до 2014. године. Исте године, анексија Крима и руска војна интервенција у источном делу земље показали су да је украјински концепт неутралности уместо на дугорочној стратегији почивао на свакодневном тактизирању између Москве, Брисела и Вашингона. ${ }^{10}$

Децембра 2014. године парламент Украјине усвојио је законски акт којим се укида неутралност и стварају услови за интеграције у евроатлантске структуре. Од тада на украјинској политичкој сцени постоји

\footnotetext{
7 Потписивање Споразума о придруживању омогућило је поступно приближавање Кијева Европској унији у наредним годинама, али Брисел није узвратио дугорочном политичком стратегијом која би водила продубљивању интеграција. Miloš M. Petrović, Nastanak Ukrajinske krize: od političke iluzije Evropske unije do bitke za postsovjetsku Evropu, Institut za međunarodnu politiku i privredu, Beograd, 2019, str. 101.

${ }^{8}$ Ana Jović-Lazić, Ivona Lađevac, „Razvoj i posledice ukrajinske krize“, Međunarodna politika, LXIX, br. 1172, 2018, str. 31.

${ }^{9}$ Igor Novaković, „Politika neutralnosti u Evropi od kraja Drugog svetskog rata do danas kao „cena" za status stalne neutralnosti: značaj za Srbiju“, op. cit., str. 46.

${ }^{10}$ Veljko Blagojević, „Potencijal politike neutralnosti Republike Srbije u savremenim međunarodnim odnosima", op. cit.
} 
снажан консензус о руским претњама украјинској државности. Током 2015. године Врховна рада (Verkhovna Rada) Украјине усвојила је низ докумената којима се осуђује континуитет руске војне агресије на Украјину. Један од њих представља и Стратегија националне безбедности, која одсликава јединствен политички наступ у борби против руске хибридне агресије. Нове спољнополитичке одреднице одређују другачији приступ по коме неутрализација руских претњи и чланство у НАТО савезу представљају стратешке приоритете. ${ }^{11}$ Током 2016. године украјинска дипломатија је задобијањем међународне подршке постигла важна достигнућа у осуди руске војне интервенције. Том приликом је усвојено више докумената: Резолуција Европског парламента од 4. фебруара 2016. године којом се осуђује „висок ниво кршења људских права почињених против становника Крима, посебно кримских Татара као староседелачког народа Крима и озбиљна ограничења слободе и мирног окупљања; Резолуција од 12. октобра 2016. године којом се на Русију ставља пуна одговорност за кршење људских права на Криму и Донбасу. Ова резолуција, између осталог, наводи да се „међународни притисак, укључујући санкције, мора одржавати како би суверенитет и територијални интегритет Украјине био у потпуности обновљен у оквиру својих међународно признатих граница“; позитиван глас о нацрту Резолуције о кршењу људских права на Криму, од стране трећег комитета Генералне Скупштине УН, који је потврдио територијални интегритет Украјине и руску анексију Крима, по основу усвајања Резолуције о људским правима на Криму Генералне Скупштине УН од 19. децембра 2016. године. Том приликом се украјинска дипломатска служба фокусирала на три кључна подручја рада: 1) консолидовано супротстављање руској агресији у Донбасу и окупираном Криму; 2) строго поштовање политике непризнавања анексије Крима и Донбаса; 3) континуитет политичког притиска на агресора, у виду санкција. ${ }^{12}$

Новом Стратегијом националне безбедности из 2020. године формулишу се специфична подручја сарадње и стратешке интеграције Украјине са кључним безбедносним и политичким системима савременог

\footnotetext{
11 "Ukrainian Prism: Foreign Policy 2016", 2017Analytical study, Foreign Policy Council "Ukrainian Prism", Friedrich Ebert Foundation, Office in Ukraine - Kyiv, p. 113.

12 "Ukrainian Prism: Foreign Policy 2016", op. cit., p. 70.
} 
света, који су тренутно највећи донатори украјинске државне егзистенције. ${ }^{13}$ Поред тога, Стратегија дефинише Русију као агресорску државу која помоћу широког спектра политичких, економских, војних, информационих и сајбер активности покушава да обнови свој утицај у Украјини. За разлику од претходне верзије из 2015. године, нова стратегија подвлачи улогу међународне заједнице у одвраћању нове, руске оружане агресије и потпуне контроле над Донбасом. У циљу очувања суверенитета и територијалног интегритета, значајну новину представља и успостављање стратешког партнерства са државама које би могле пружити Украјини безбедносне гаранције. На листи ових земаља приоритет се даје САД, Великој Британији, Канади, Немачкој и Француској. На основу изнетих приоритета у Стратегији из 2020. године, могу се извести два тумачења. Према првом објашњењу, Украјина изостављањем Минског споразума, као и преговора у Нормандијском формату, оставља простор за нова, ефективнија решења. На основу тога и поменуте листе стратешких партнера може се закључити да једна од нових опција подразумева да се даљи ток преговора са Русијом одвија посредством Европске уније, НАТО савеза и ОЕБС-а. ${ }^{14}$ Друго тумачење је мање оптимистично, јер демантује мирнодопску реторику Зеленског на основу украјинског гранатирања самопроглашене Доњецке Народне Републике у марту 2021. године. Овај догађај се може повезати са наоружавањем Украјине, као прве државе која је по доласку Џозефа Бајдена (Joseph Biden) на власт добила војну помоћ у износу од 125 милиона долара. ${ }^{15}$

Недавном ескалацијом сукоба у источном делу земље, већ напети односи Русије и Украјине добијају нове безбедносне, али и економске импликације. Не сме се пренебрегнути чињеница да Русија и даље има важну улогу за украјинску економију, због чега су финансијске активности Украјине ограничене на употребу руске енергетске полуге. Прелиминарна

\footnotetext{
13 "Ukrainian Prism: Foreign Policy 2016", Analytical study, Foreign Policy Council "Ukrainian Prism", Friedrich Ebert Foundation, Office in Ukraine - Kyiv, 2017, p. 69.

${ }^{14}$ Daniel Szeligowski, "Ukraine`s New National Security Strategy", 30.10.2020, https:// www.pism.pl/publications/Ukraines_New_National_Security_Strategy, 03/06/2021.

${ }^{15}$ Aaron Mehta and Howard Altman, "US announces $\$ 125$ million in military aid for Ukraine", 01/03/2021, https://www.defensenews.com/global/europe/2021/03/01/us-announces125-million-in-military-aid-for-ukraine/, 07/05/2021.
} 
идеја Северног тока 2 обухватала је Украјину као незаобилазну тачку посредством које се природни гас из Русије директно транспортује до Немачке и средишњег европског простора. ${ }^{16}$ Међутим, диверзификацијом енергетског тока Русија је угрозила позицију Украјине као транзитне државе, и на дугорочно оштетила њен највећи извор прихода од којег је зарађивала милијарду долара на годишњем нивоу. ${ }^{17}$ Политичке и економске последице сукоба на Криму могу се осетити и када је реч о регулисању поморских трговинских путева. Управљање њиховим токовима постаје нарочито проблематично након 2014. године, посебно у случају Керчког мореуза и Азовског мора. Ово плитко поморско подручје, које укључује узак пролаз између Крима и руског копна, има важну улогу у поморској економији Русије и Украјине. Велике количине терета пролазе кроз Керчки мореуз до руских лука у Азовском мору, као и украјинских лука Мариупол и Берђанск. Мариупол је традиционално важно средиште за испоруку челика, угља, гвоздене руде и других металуршких производа. До 2014. године су ове две украјинске луке чиниле приближно једну четвртину украјинског поморског извоза, да би тај износ након анексије Крима постао знатно мањи. ${ }^{18}$ Већина украјинске економске зоне изван обала Крима експлоатисана је од стране руских компанија, које су искористиле експроприанисане потенцијале пуштене у производњу након анексије. Руским рибарима је омогућен приступ морским ресурсима у водним подручјима којима је раније управљала Украјина. Руско војно присуство на кримском полуострву и у суседним водама постало је главни извор забринутости украјинских планера одбране који су одлучили да отприлике две трећине украјинских војних јединица, које су раније биле смештене на Криму, интегришу у 22. армијски корпус Црноморске флоте која је основана 2016. године. Као резултат погоршане безбедносне ситуације Украјина је изгубила већи део морнарице, укључујући 75\% особља и 70\% бродова и

\footnotetext{
${ }^{16}$ Maddy White, "Nord Stream 2 spells pain for Ukraine", Global Trade Review, 14/01/2021, https://www.gtreview.com/magazine/volume-18-issue-1/nord-stream-2-spells-painukraine/, 10/05/2021.

${ }^{17}$ Mark Temnycky," "The Security Implications of Nord Stream 2 for Ukraine, Poland and Germany", Wilson center, 17/03/2021, https://www.wilsoncenter.org/blog-post/securityimplications-nord-stream-2-ukraine-poland-and-germany, 15/05/2021.

${ }^{18}$ Kristian Åtland, "Redrawing borders, reshaping orders: Russia's quest for dominance in the Black Sea region", European Security, Vol. 30, No. 2, 2021, p. 11.
} 
обалске инфраструктуре. ${ }^{19}$ Руска стратегија поморског експлоатисања у Азовском мору има доста сличности са политиком која се водила у источном делу Црног мора након руско-грузијског рата 2008. године. Русија и даље контролише 20\% копнене територије Грузије, док су територијалне воде Грузије у близини обале Абхазије третиране као саставни део територијалних вода Русије. ${ }^{20}$

Безбедносне и економске импликације сукоба на Криму одражавају последице квази-неутралне политике која је угрозила територијалну целовитост Украјине. Санкције и притисци на Русију прикривају недостатак визије Запада у вези са стабилизацијом Украјине и ширег региона. Таква стабилизација мора проћи кроз свеобухватан пакет политичких и економских мера, укључујући и неутралност Украјине као гаранцију за њену безбедност, суверенитет и аутономију захваљујући којој ће Кијев одржавати јаке комерцијалне везе са ЕУ, али и Евроазијском економском унијом. ${ }^{21}$ Сходно реченом, успостављање трајне неутралности би посредством енергетских, трговинских и других веза допринело другачијој клими билатералних односа Русије и Украјине, па самим тим и смиривању територијалних напетости.

\section{Перспективе чланства Украјине у НАТО савезу}

Након преврата 2014. године САД остварује велики утицај на Украјину тиме што подржава тврду антируску политику на унутрашњем плану, али и већу приврженост евроатлантским интеграционим процесима. ${ }^{22}$ HАTO у овом периоду добија значајно место у стратешким документима Украјине, где се нагласак ставља на интероперабилност оружаних снага Украјине НАТО стандардима и јачање војне и политичке сарадње са државама чланицама. Посебна пажња се посвећује државном програму реформе и развоју

${ }^{19}$ Kristian Åtland, "Redrawing borders, reshaping orders: Russia's quest for dominance in the Black Sea region", op. cit., p. 12.

${ }^{20}$ Kristian Åtland, "Redrawing borders, reshaping orders: Russia's quest for dominance in the Black Sea region", op. cit., p. 15.

${ }^{21}$ Andrei Tsygankov, "Vladimir Putin's last stand: the sources of Russia's Ukraine policy", Post-Soviet Affairs, Vol. 31, No. 4, 2015, p. 299.

22 Драган Петровић, „Отопљавање Украјинске кризе?!“, Култура полиса, XVII, Број 42, 2020, стр. 253. 
одбрамбено-индустријског комплекса за период до 2020. године. Украјина активно сарађује са НАТО савезом на свим нивоима - председничком, парламентарном и извршном, на нивоу Министарства одбране, Министарства спољних послова итд. Агенда њихове сарадње се састоји од редовних посета, када се одржавају редовни састанци заједничке Радне групе НАТО-Украјина за одбрамбено техничку сарадњу. Током председовања Петра Порошенка (Петро́ Олексійович Пороше́нко), вођени су дуготрајни преговори са генералним секретаром Алијансе, Јенсом Столтенбергом (Jens Stoltenberg). Том приликом је одржано седам састанака, посебно на председничком и владином нивоу. Украјински мировњаци су наставили своје учешће у НАТО мисијама на Косову и Авганистану. Поред тога, страни инструктори су обучили пет украјинских батаљона по НАТО стандардима. Као успешни примери институционалне сарадње могу се навести акције за подршку украјинских политичких затвореника, продужење санкција против Русије, укључујући подршку међународних организација. Упркос активној сарадњи и активностима Украјине при НАТО савезу, треба напоменути да се одсуство њеног шефа током једне и по године негативно одразило на ниво њихове комуникације.. ${ }^{23}$ Друга важна тачка њихове сарадње огледа се у томе што Украјина није именовала амбасадоре у значајном броју европских земаља, што може бити лош сигнал за европске партнере. Такође, једно време је као отправник послова мисијом Украјине при НАТО савезу руководио Бозхок (Єгор Валерійович Божок), бивши председник украјинске обавештајне службе, због чијег постављења западни партнери сумњају у лојалност украјинске дипломатске службе. ${ }^{24}$

Украјина своје законе из области безбедносне и одбрамбене политике такође прилагођава Вашинпонском споразуму НАТО савеза, према којима би за трошкове овог ресора требало да издвоји најмање 5\% бруто домаћег производа, од чега најмање 3\% на финансирање одбрамбених снага. Иако је у великој мери присутан наратив да се чланство Украјине у НАТО савезу предложи као једна од нових одредби њеног Устава, коначна одлука би требало да буде донета на основу референдума. ${ }^{25}$ Према резултатима

\footnotetext{
23 "Ukrainian Prism: Foreign Policy 2016", op. cit., p. 69.

24 "Ukrainian Prism: Foreign Policy 2016", op. cit., p. 70.

${ }^{25}$ Hennadiy Maksak, "The security perception and security policy of Ukraine, 1991-2018", Defense \& Security Analysis, Vol. 37, No. 1, 2021, p. 70.
} 
истраживања јавног мњења из 2020. године, придруживање НАТО савезу не би требало да постане саставни део устава Украјине, о чему говори проценат од 50,4\% грађана који сматрају да је за њихову државу најбоље да усвоји неутралан, односно ванблоковски статус. ${ }^{26}$

Исход евентуалног пријема у НАТО могао би угрозити одбрамбену доктрину Русије, јер би НАТО дошао на само 450 км ваздушном линијом од Москве, што је у оквиру домета тактичких пројектила. ${ }^{27}$ Међутим, чланство Украјине у НАТО савезу није изгледно уколико се посматра став јавног мњења, али и непоколебљива одлука Алијансе да не прихвата државе које имају спорне територије. Добар пример на који се Украјина том приликом може угледати јесте Грузија, која од дана стицања независности тежи пријему у Алијансу. Њена одлука је, за разлику од Украјине, подржана од стране јавног мњења на референдуму 2008. године. ${ }^{28}$ Алијанса је заузврат изричито подржала територијални интегритет и суверенитет Грузије „унутар њених међународно признатих граница“ и позвала Русију да „поништи своје признање региона Абхазије и Јужне Осетије“. ${ }^{29}$ Међутим, традиционално добро споразумевање није резултовало придруживањем Грузије НАТО савезу, чак ни после скоро три деценије. Разлоге треба превасходно тражити у територијалном спору који је довео до „замрзнутог партнерства“, као идеалног модела односа који

${ }^{26}$ Gerard Toal, John O'Loughlin and Kristin M. Bakke, "Is Ukraine caught between Europe and Russia?", The Washington Post, 26. 02. 2020, https://www.washingtonpost. com/politics/2020/02/26/is-ukraine-caught-between-europe-russia-we-asked-ukrainiansthis-important-question/, 20/05/2021. Према другим изворима проценат варира, па тако 44\% подржава придруживање НАТО савезу, док 26\% подржава војну сарадњу са Русијом. Свакако резултати истраживања јавног мњења иду у прилог поновној неутралности Украјине. Mike Sweeney, “Saying „NO" to NATO - Options for Ukranian neutrality", Defence Priorities.org, August 2020.

${ }^{27}$ Vladimir Trapara, „Savremeni značaj Makinderovog koncepta istočne Evrope: slučaj ukrajinske krize", Međunarodna politika, Vol. LXV, br. 1155-1156, 2014, str. 37.

${ }^{28}$ Shubitidze, Vaja, Otar Davitashvili, and Edisher Japharidze. "Prospects for Georgia`s integration into NATO", 2021, Editorial Board, p. 225.

${ }^{29}$ Farid Guliyev \& Andrea Gawrich, "NATO vs. the CSTO: security threat perceptions and responses to secessionist conflicts in Eurasia", Post-Communist Economies, 2020, Vol. 33, No. 2-3, pp. 283-304. О геополитичким карактеристикама Украјине погледати више у раду: Драган Петровић, „Геополитички аспекти савремене Украјине“, Глобус, Српско географско друштво, бр. 32, 2007, стр. 177-188. 
Алијанса жели да развија са просторно недефинисаним државама. Ако упоредимо ставове јавног мњења Украјине и Грузије у идентичном, послератном периоду, можемо запазити да у првом случају има много више опонената војном сврставању. Отуда политика коју Украјина води за време писања овог рада има нерационалан ток, који одражава дубоке поделе у политичком животу и укупним опредељењима грађана.

\section{Закључак: консензус о украјинској неутралности}

Међу појединим члановима домаће, али и стране, академске заједнице постоји консензус о томе да усвајање политике неутралности представља једино одрживо решење украјинске кризе. У складу са тиме неколицина аутора предлаже различите моделе неутралности који би допринели превазилажењу „геополитичке дилеме“, у којој се Украјина налази. ${ }^{30}$ Један од домаћих аутора, Владимир Трапара, као компромисно решење украјинске кризе предлаже модел федерализације државе и гарантовану војну неутралност која би на глобалном плану одвратила Вашингтон од експанзионистичке политике на простору Источне Европе. ${ }^{31}$ Идеја о федерализацији државе била би лепо прихваћена од стране Русије, будући да је њен стратешки циљ у вези са украјинском кризом био усмерен управо ка федерализација земље или макар снажној регионализацији. ${ }^{32}$ Неутралност Украјине има своје присталице и међу члановима стране академске заједнице, попут Стивена Волта (Stephen Walt) који тврди да трајна неутралност Украјине омогућава да се економски одржи уз подршку ЕУ, али и других међународних институција. ${ }^{33}$ Сваки покушај наоружавања Украјине може довести само до ескалације сукоба, што смо могли приметити након Бајденове прве војне донације упућене Кијеву. Дмитриј

\footnotetext{
30 Heinz Gärtner, "The Model of Neutrality The Example of East-Central European States", op. cit., p.93.

${ }^{31}$ Vladimir Trapara, "Savremeni značaj Makinderovog koncepta Istočne Evrope”, op. cit., str. 41.

32 Драган Петровић, Рајко Буквић, Украјинска криза 2013-2019, Институт за међународну политику и привреду, Београд, 2019, стр 159.

${ }^{33}$ Stephen M. Walt, "Why Arming Kiev Is a Really, Really Bad Idea," Foreign Policy, 09/02/2015, https://foreignpolicy.com/2015/02/09/how-not-to-save-ukraine-armingkiev-is-a-bad-idea/, 25/05/2021.
} 
Тренин (Дмитрий Витальевич Тренин) сугерише да би Русија прихватила неутралну Украјину, као легитимну спољнополитичку опцију која не искључује чланство у ЕУ, али елеминише сваку могућност пријема у НАТО. ${ }^{34}$ Грахам Алисон (Graham Allison) за разлику од претходних аутора има далекосежнији предлог украјинске неутралности. Ако цела територија Украјине (минус Крим) остане суверена ванблоковска држава, Украјина би се морала сложити са свим странама да ће остати неутрална по питању војних, али и економских односа у наредних четврт века. ${ }^{35}$ у својој аргументацији Алисон користи историјске примере белгијске неутралности у 19. веку, као и аустријске и финске неутралности након Другог светског рата. ${ }^{36}$ Близак Алисоновим историјским налазима је Збигњев Бжежински (Zbigniew Kazimierz Brzeziński), који препоручује финландизацију Украјине по аналогији територијалне блискости са Русијом, добрих односа са Истоком и Западом, као и војним несврставањем. .7, $38^{2}$

Прегледом литературе се може установити да је највећи број аутора за усвајање неутралности по аустријском моделу. Он би, поред закона о неутралности, подразумевао и уговор који забрањује да се Украјина придружи Русији, али и да се мора разјаснити будући статус Крима са различитим етничким и језичким групама (Руси, Украјинци и кримски Татари). Темељ за поштовање мањинских права могао би да представља споразум из Минска 2015. године, који каже да би нови Устав требало да предвиђа „децентрализацију као кључни елемент, укључујући специфичности Доњецке и Луганске области“. По узору на кипарски модел, дошло би до поделе Донбаса, посебно ако би мировне снаге УН биле распоређене на линији разграничења како то предлаже Москва. Други

${ }^{34}$ Dimitri Trenin, "Avoiding U.S.-Russia Military Escalation During the Hybrid War", Carnegie Moscow Center, 2018.

${ }^{35}$ Graham Allison, "Could the Ukraine Crisis Spark a World War?", The National Interest, 2014.

${ }^{36}$ Heinz Gärtner, "The Model of Neutrality The Example of East-Central European States", op. cit., p.101.

${ }^{37}$ Zbigniew Brzezinski, "Russia needs a 'Finland option' for Ukraine”, Financial Times, 2014.

${ }^{38}$ Иако је аустријско председавање ОЕБС-ом 2017. године, као и ЕУ у другој половини 2018. године, имало прилику да се позабави питањем неутралности за источноевропске државе, укључујући Молдавију, до тога није дошло. Heinz Gärtner, "The Model of Neutrality The Example of East-Central European States", op. cit., p. 98. 
модел би подразумевао постепени повратак Донбаса под потпуну контролу Кијева, уз помоћ међународних организација. У том случају би покренута мировна мисија УН de facto резултирала сарадњом Русије и Запада. ${ }^{39}$ Као дипломатско решење, аустријски модел може бити атрактивна алтернатива за Украјину. У оптимистичној визији коју нуди Scenario Group Ukraine 2027, континуирана политика попуштања Русије и Запада могла би да резултира новим безбедносним споразумима у којима је Украјина призната као трајно неутрална држава. ${ }^{40}$ Такав статус би био прихватљив за Брисел, Москву, Вашингтон и Кијев. Постојале би гаранције да ниједна страна неће користити силу за промену статуса, док би неутрална Украјина и даље била наоружана, подсећајући на аустријски модел. ${ }^{41}$

Политика балансирања између ЕУ и САД, с једне, и Русије с друге стране, годинама је била једна од карактеристика спољнополитичке оријентације Украјине. ${ }^{42}$ Међутим, сада је дошло до радикалне промене у њеним стратешким приоритетима и политика неутралности више није правац којем Украјина тежи. Предложени модели украјинске неутралности почивају на различитим објашњењима, при чему нашу аргументацију и темељимо на амплитуди „одмрзавања“ конфликта, која је најмања код војно неутралних држава. То значи да државе које имају неутралан статус и замрзнути конфликт на својој територији, нису забележиле ниједан случај ескалације сукоба. Под овим државама убрајамо Републику Молдавију и Републику Србију. ${ }^{43}$ Попут Украјине, две поменуте државе имају замрзнуте конфликте на својој територији (Косово и Придњестровље), при чему

${ }^{39}$ András Rácz, "Wither or Return to the West? An Analysis of the New Russian Peacekeeping Proposal on Eastern Ukraine", EU Frontier Policy Brief No. 23 - Center for European Neighborhood Studies, 2018.

40 "Foresight Ukraine, Four Scenarios for the Development of Ukraine", Scenario Group Ukraine 2027, Friedrich Ebert Stiftung, 2017.

${ }^{41}$ Heinz Gärtner, "The Model of Neutrality The Example of East-Central European States", op. cit., p. 94.

${ }^{42}$ Ana Jović-Lazić, Odnosi između Evropske unije i Ruske Federacije: kraj XX i početak XXI veka, Institut za međunarodnu politiku i privredu, Beograd, 2015, str. 217-228.

${ }^{43}$ Више о војној неутралности Републике Србије у контексту регионалне безбедности погледати y: Elena S. Ponomareva, Dušan Proroković, "NATO VS. RUSSIA: IMPACT ON BALKAN REGIONAL SECURITY", in: Katarina Zakić and Birgül Demirtaş (eds.), Europe in changes: The old continent at a new crossroads, 2021, pp. 117-139. 
успевају да неутралним статусом одрже стање релативног мира и одврате сваку могућност оружане агресије друге државе или пак организације. С друге стране, Грузија, Јерменија и Азербејџан периодично пролазе кроз фазе заоштравања сукоба на спорним територијама. Као чланица Организације уговора о колективној безбедности, Јерменија није имала никакве безбедносне гаранције да ће у случају евентуалне оружане агресије на територију Нагорно-Карабаха уживати подршку од стране других држава чланица, у виду колективне одбране. Према томе, обнављање непријатељстава у Нагорно-Карабаху 2020. године може послужити Украјини као опомена да блоковски статус нема снагу одвраћања у случају тињајућих сукоба ниског интензитета. Сличан, а можда и гори сценарио од сукоба у Нагорно-Карабаху, могао би очекивати Украјину уколико се једног дана одважи да постане чланица НАТО савеза или неке друге војне алијансе. Поучена искуством других земаља, Украјина би требало да стреми успостављању трајне неутралности, која у новим, измењеним околностима представља успешну и одрживу политику балансирања.

\section{Библиографија}

"Foresight Ukraine, Four Scenarios for the Development of Ukraine", Scenario Group Ukraine 2027, Friedrich Ebert Stiftung, 2017.

"Ukrainian Prism: Foreign Policy 2016", Analytical study, Foreign Policy Council "Ukrainian Prism", Friedrich Ebert Foundation, Office in Ukraine - Kyiv, 2017, p. 113.

Allison, Graham, "Could the Ukraine Crisis Spark a World War?", The National Interest, 2014.

Åtland, Kristian, "Redrawing borders, reshaping orders: Russia's quest for dominance in the Black Sea region", European Security, Vol. 30, No. 2, 2021, pp. 2-21.

Blagojević, Veljko, „Potencijal politike neutralnosti Republike Srbije u savremenim međunarodnim odnosima“, u: Srđan T. Korać (ur.), Uticaj vojne neutralnosti Republike Srbije na bezbednost i stabilnost u Evropi, 2016, str. 240-259.

Brzezinski, Zbigniew, "Russia needs a 'Finland option' for Ukraine”, Financial Times, 2014. 
Gärtner, Heinz, "The Model of Neutrality The Example of East-Central European States", in: Herbert R. Reginbogin and Pascal Lottaz (eds.), Permanent Neutrality: A model for Peace, Security and Justice, Lexington Books, Lanham, 2020, pp. 89-111.

Guliyev, Farid \& Gawrich, Andrea, "NATO vs. the CSTO: security threat perceptions and responses to secessionist conflicts in Eurasia", PostCommunist Economies, 2020, Vol. 33, No. 2-3, pp. 283-304.

Jović-Lazić, Ana, Lađevac, Ivona, "Razvoj i posledice ukrajinske krize“, Međunarodna politika, Vol. LXIX, br. 1172, 2018, str. 27-51.

Jović-Lazić, Ana, Odnosi između Evropske unije i Ruske Federacije: kraj XX i početak XXI veka, Institut za međunarodnu politiku i privredu, Beograd, 2015.

Maksak, Hennadiy, "The security perception and security policy of Ukraine, 1991-2018", Defense \& Security Analysis, Vol. 37, No. 1, 2021, p. 53-65.

Mehta, Aaron and Altman, Howard, US announces $\$ 125$ million in military aid for Ukraine", 01/03/2021, https://www.defensenews.com/global/europe/ 2021/03/01/us-announces-125-million-in-military-aid-for-ukraine/, 07/05/2021.

Novaković, S. Igor, „Politika neutralnosti u Evropi od kraja Drugog svetskog rata do danas kao "cena" za status stalne neutralnosti: značaj za Srbiju“, u: Srđan T. Korać (ur.), Uticaj vojne neuralnosti Srbije na bezbednost i stabilnost u Evropi, 2016, str. 11-29.

Petrović, M. Miloš, Nastanak Ukrajinske krize: od političke iluzije Evropske unije do bitke za postsovjetsku Evropu, Institut za međunarodnu politiku i privredu, Beograd, 2019.

Ponomareva, S. Elena and Proroković, Dušan, "NATO VS. RUSSIA: IMPACT ON BALKAN REGIONAL SECURITY", in: Katarina Zakić and Birgül Demirtaş (eds.), Europe in changes: The old continent at a new crossroads, 2021, pp. 117139.

Rácz, András, "Wither or Return to the West? An Analysis of the New Russian Peacekeeping Proposal on Eastern Ukraine", EU Frontier Policy Brief No. 23 - Center for European Neighborhood Studies, 2018.

Sweeney, Mike, "Saying "NO" to NATO - Options for Ukranian neutrality", Defence Priorities.org, 2020. 
Szeligowski, Daniel, "Ukraine`s New National Security Strategy", 30.10.2020, https://www.pism.pl/publications/Ukraines_New_National_Security_Strate gy, 03/06/2021.

Temnycky, Mark, "The Security Implications of Nord Stream 2 for Ukraine, Poland and Germany", Wilson center, 17/03/2021, https://www.wilsoncenter.org/ blog-post/security-implications-nord-stream-2-ukraine-poland-andgermany, 15/05/2021.

Toal, Gerard, O'Loughlin, John and Bakke, M. Kristin, "Is Ukraine caught between Europe and Russia?", The Washington Post, 26. 02. 2020, https://www.washingtonpost.com/politics/2020/02/26/is-ukraine-caughtbetween-europe-russia-we-asked-ukrainians-this-importantquestion/ https://www.washingtonpost.com/politics/2020/02/26/is-ukraine-caughtbetween-europe-russia-we-asked-ukrainians-this-important-question/, 20/05/2021.

Trapara, Vladimir, „Savremeni značaj Makinderovog koncepta istočne Evrope: slučaj ukrajinske krize", Međunarodna politika, Vol. LXV, br. 1155-1156, 2014, str. 26-43.

Trenin, Dimitri, "Avoiding U.S.-Russia Military Escalation During the Hybrid War", Carnegie Moscow Center, 2018.

Tsygankov, Andrei, "Vladimir Putin's last stand: the sources of Russia's Ukraine policy", Post-Soviet Affairs, Vol. 31, No. 4, 2015, pp. 279-303.

Vaja, Shubitidze, Davitashvili, Otar, and Japharidze, Edisher. "Prospects for Georgia 's integration into NATO", 2021, Editorial Board, p. 225.

Walt, M. Stephen, "Why Arming Kiev Is a Really, Really Bad Idea", Foreign Policy, 09/02/2015, https://foreignpolicy.com/2015/02/09/how-not-to-saveukraine-arming-kiev-is-a-bad-idea/, 25/05/2021.

White, Maddy, "Nord Stream 2 spells pain for Ukraine", Global Trade Review, 14/01/2021, https://www.gtreview.com/magazine/volume-18-issue-1/ nord-stream-2-spells-pain-ukraine/, 10/05/2021.

Петровић, Драган, „Геополитички аспекти савремене Украјине“, Глобус, Српско географско друштво, Бр. 32, 2007, стр. 177-188.

Петровић, Драган, „Отопљавање Украјинске кризе?!“, Култура полиса, XVII, Број 42, 2020, стр. 247-260. 
Петровић, Драган, Буквић, Рајко, Украјинска криза 2013-2019, Институт за међународну политику и привреду, Београд, 2019.

Петровић, Драган, Председнички избори у Украјини 2010, Институт за међународну политику и привреду, Београд, 2010.

\title{
NEUTRALITY OF THE REPUBLIC OF UKRAINE: SUSTAINABLE POLICY UNDER NEW CIRCUMSTANCES
}

\begin{abstract}
The end of the war in Crimea and the freezing of the conflict in Donbas are the conditions for the birth of a new epoch of the foreign policy of the Republic of Ukraine. In the content of its post-war, institutional documents, the narrative about Russia as an "aggressor" prevails, which determines its historical right and the partnership with the NATO alliance as a new strategic goal. After 2014, Ukraine's security and defense policy became in favor of the North Atlantic Alliance, which is why discussions about its eventual membership were often initiated. The real chances of such a scenario are diminished by considering the Russian perspective, but also by the decision of the NATO alliance not to accept countries that have a frozen conflict on their territory. A good example that Ukraine can follow is Georgia, whose experience reflects the unwavering attitude of the North Atlantic community towards the rejection of countries with disputed territories. It follows from the above that smoldering low-intensity conflicts encourage states to adopt various security strategies. If we assess their success based on the amplitude of the "thawing" of the conflict, then it can be concluded that its value is the lowest in military-neutral countries. Taking into account all the above factors, the main hypothesis of the paper is that the re-adoption of the permanent neutral status of the Republic of Ukraine leads to a sustainable policy of balancing in the changed circumstances. Using qualitative analysis of the security policy of the Republic of Ukraine, the paper manages to decipher its official attitude towards Russia, as well as the realistic prospects for NATO membership. Considering different perspectives, the argument about the re-adoption of military neutrality, which Ukraine advocated until 2014, is confirmed.
\end{abstract}

Keywords: neutrality, Republic of Ukraine, Russia, NATO. 